\title{
Effects of dietary energy allowance in grass silage-based diets during the dry period on production responses and utilization of body reserves in dairy cows
}

\author{
Tuomo Kokkonen ${ }^{1}$, Siru Salin ${ }^{1}$, Seija Jaakkola ${ }^{1}$, Juhani Taponen ${ }^{2}$, Kari Elo ${ }^{1}$ and Aila Vanhatalo ${ }^{1}$ \\ ${ }^{1}$ Department of Agricultural Sciences, P.O. Box 28, Fl-00014 University of Helsinki, Finland \\ ${ }^{2}$ Department of Production Animal Medicine, University of Helsinki, Paroninkuja 20, \\ FI-04920 Saarentaus, Finland \\ e-mail: tuomo.kokkonen@helsinki.fi
}

\begin{abstract}
The aim was to study if overconsumption of grass silage during the far-off dry period (FODP) and decreasing feed allowance in close-up dry period (CUDP) affect body condition score (BCS) and body weight (BW) changes, as well as lactation performance and body tissue mobilization after calving in dairy cows. Control diet (CON) was fed to meet the metabolizable energy (ME) requirements, the test diet (HEI) averaged $144 \%$ and $119 \%$ of ME requirements in the FODP and CUDP, respectively. All cows were fed concentrates in the CUDP $\left(30 \%\right.$ of ME $\left.\mathrm{d}^{-1}\right)$. Plasma non-esterified fatty acids (NEFA) were lower and insulin tended to be higher in HEI vs. CON prepartum. No dietary effects in accretion or mobilization of body reserves were observed, and accordingly no differences in silage DMI, $\mathrm{ME}$ balance and plasma parameters postpartum were detected. Concentrate DMI and milk yield tended to be lower in $\mathrm{HEI}$ vs. CON during early lactation.
\end{abstract}

Key words: transition period, energy intake, body condition, lactation, insulin

\section{Introduction}

Maximizing feed intake during the early weeks of lactation is one of the key elements of successful transition from pregnancy to lactation. Elevated energy intake (EI) before parturition and the subsequent greater body condition score (BCS) at calving have been linked to lower dry matter intake (DMI) after parturition (Douglas et al. 2006, Janovick and Drackley 2010). The negative effect on DMI is partly due to greater lipid mobilization leading to higher availability of fatty acids for hepatic oxidation, enhancing the hepatic vagal satiety signaling to the brain (Allen et al. 2009).

Controlling El prepartum improved the rate of DMI increase and the total DMI in early lactation (Agenäs et al. 2003, Douglas et al. 2006, Janovick and Drackley 2010). Prepartal diets that meet or fall behind the ME requirements decreased lipid mobilization postpartum (Kokkonen et al. 2005, Douglas et al. 2006), and milk fat concentration (Keady et al. 2001, Agenäs et al. 2003). Other studies, however, showed no effects of pre-calving El on postpartal lipid mobilization (Tesfa et al. 1999) or DMI (Keady et al. 2005, Winkelman et al. 2008). Discrepancies between the studies are at least partly explained by differences in the diet composition (e.g. inclusion of maize vs. grass silage (GS) or dietary concentrate proportion), energy levels and the duration and the timing of the overfeeding, and ultimately the degree of induced differences in body fatness. Specifically, overfeeding of energy during the far-off dry period (FODP) may have a greater negative impact on peripartum metabolic adaptations than close-up dry period (CUDP) nutritional strategies. Indeed, feeding according to or below the energy requirements, as compared to ad libitum feeding during the FODP resulted in lower circulating postpartal NEFA with a positive effect on DMI and energy intake during the first weeks of lactation (Dann et al. 2006, Cardoso et al. 2013).

A common approach in supplying extra energy in the prepartum diet is to increase the level of concentrate in the ration (Remppis et al. 2011). The research on the effect of GS allowance as sole feed in dairy cows during the FODP is limited to few studies (Dewhurst et al. 2009, Little et al. 2016). Accordingly, the effect of decreasing the oversupply of El during the CUDP has not been studied experimentally on GS, although large changes in prepartal DMI have been linked to lower postpartal DMI (Grummer et al. 2004). Despite results showing that excess allowance of energy in the dry period may contribute the decline in DMI before parturition (Douglas et al. 2006, Dann et al. 2006, Janovick and Drackley 2010), the drop in DMI is not universal, suggesting smaller effects on GS-based diets (Agenäs et al. 2003, Dewhurst et al. 2009). 
The objective of this study was to investigate whether overconsumption of GS during the FODP and decreasing feed allowance in CUDP affect BCS and body weight (BW) changes as well as lactation performance and body tissue mobilization after calving in dairy cows. The adopted feeding approach was chosen to ensure a substantial decrement in DMI in the context of overfeeding of grass silage and close-up feeding with concentrate. Adipose tissue and hepatic gene expression from the same experiment were presented in earlier publications by Selim et al. (2014) and results of intravenous glucose tolerance test by Salin et al. (2017). The hypothesis of the present study was that GS-based high energy feeding during the dry period accompanied by a substantial decrease of feed intake before calving would increase lipid mobilization and decrease DMI after calving when compared with controlled energy feeding.

\section{Material and methods}

\section{Cows, diets, and experimental design}

The experimental procedures were conducted under the protocols approved by the National Animal Ethics Committee in Finland (Hämeenlinna). The study was conducted with 16 Finnish Ayrshire cows, using a randomized complete block design. The cows were paired according to their expected calving dates, parity ( 2 nd to 4 th calving), BW $[693 \pm 56.8 \mathrm{~kg}$ (mean \pm SD)], and BCS (3.7 \pm 0.3$)$. Cows were housed in tie stalls with sawdust bedding and rubber mats throughout the dry period. They had continuous access to water and salt licks. Three days before expected parturition, cows were moved to individual calving pens until parturition. After parturition, each cow was moved back to the same tie stall which she had occupied before calving. The tie stalls and maternity boxes were equipped with roughage intake control systems (Insentec BV, Marknesse, the Netherlands), and fitted with separate concentrate troughs. After two weeks of lactation, the cows were moved to a free-stall barn equipped with a roughage intake control system (Insentec BV, Marknesse, the Netherlands) and automatic concentrate feeders (Lely Cosmix, Lely Industries N.V., Maassluis, the Netherlands).

Cows were dried-off on average $63( \pm 8.9)$ days before the expected calving date. Six weeks before their expected calving dates ( $44 \pm 5$ days prior to the actual calving date), the cows were allocated to one of the two treatment groups. The treatments consisted of controlled energy feeding (CON) according to the metabolizable energy (ME) requirements of pregnant cows (Luke, 2018) or high energy feeding (HEI) targeted to supply $150 \%$ of ME requirements during the FODP. In the HEI treatment, decreasing feed allowance was implemented during the last three weeks of pregnancy to study the combined effect of high El during the FODP and the diminishing feed intake with approaching calving. The energy allowance was decreased by $5 \%$ on alternate days. The energy allowance of the HEI cows met $100 \%$ of the requirements by the day of the expected parturition and this allowance was maintained until calving. Both groups were fed second-cut GS (grass silage 1, digestible OM concentration in DM [D-value] 664 $\mathrm{g} \mathrm{kg}^{-1}$ of DM) during the dry period (Table 1). Silage was ensiled in round bales. Before baling a formic acid based additive (760 $\mathrm{g}$ of formic acid and $55 \mathrm{~g}$ of ammonium formate, AIV2 Plus, Kemira Ltd, Helsinki, Finland) was applied at a recommended rate of 5 I tonne ${ }^{-1}$.

During the last 3 weeks of pregnancy silage was supplemented with $2-3 \mathrm{~kg} \mathrm{DM} \mathrm{d}^{-1}$ (30\% of daily ME allowance) cereal concentrate (Suomen Rehu, Hankkija Agriculture, Hyvinkää, Finland) (Table 1). Silage and concentrate were fed separately twice a day (at 0700 and 1700 h). A commercial mineral and vitamin supplement (Tunnu-Melli, Raisio Feed Ltd, Raisio, Finland) ration of $0.2 \mathrm{~kg} \mathrm{~d}^{-1}$ was top-dressed once daily on forage. After calving, all cows were offered wilted first-cut GS (grass silage 2) ensiled in a bunker silo with a formic acid-based additive (AIV2 Plus, 5 I tonne ${ }^{-1}$ ). Grass silage (D-value $700 \mathrm{~g} \mathrm{~kg}^{-1}$ of DM) was fed ad libitum and supplemented with an increasing amount of the same cereal concentrate as before calving and a protein supplement consisting of rape seed expeller, rape seed meal and soya bean meal (Suomen Rehu, Hankkija Agriculture, Hyvinkää, Finland) (Table 1). In addition, $0.2 \mathrm{~kg} \mathrm{~d}^{-1}$ of a commercial mineral and vitamin supplement (Pihatto-Melli Plus, Raisio Feed Ltd, Raisio, Finland) was fed. The proportions of cereal concentrate and protein supplement were $82 \%$ and $18 \%$ of the daily concentrate ration. The rate of increase of concentrate was similar for all cows, and the maximum amount (16 kg $\left.\mathrm{d}^{-1}\right)$ was achieved on $\mathrm{d} 32$ of lactation. At the day of calving, the daily concentrate amount was $5 \mathrm{~kg} \mathrm{~d}^{-1}$. The ration was increased by $2 \mathrm{~kg} \mathrm{~d}^{-1}$ on lactation days 2, 7 and 12; by $1.5 \mathrm{~kg} \mathrm{~d}^{-1}$ on days 17 and 22; and by $1 \mathrm{~kg} \mathrm{~d}^{-1}$ on days 27 and 32. During the first two weeks of lactation, silage was distributed 4 times per day (at 0700, 1000, 1400, and $1700 \mathrm{~h}$ ), and the daily concentrate ration was fed 5 times per day (at 0700, 1000, 1400, 1700, and $2000 \mathrm{~h}$ ). During lactation weeks 3 to 8, silage was distributed 4 times per day (at 0700, 1000, 1400, and $1700 \mathrm{~h}$ ), and concentrates were offered from automatic concentrate feeders (Lely Cosmix, Lely Industries N.V., Maassluis, the Netherlands). 
Table 1. Chemical composition and calculated energy content of forages and concentrates

\begin{tabular}{|c|c|c|c|c|}
\hline & Grass silage $1^{+}$ & Grass silage $2^{\ddagger}$ & Cereal concentrate ${ }^{\S}$ & Protein supplement ${ }^{\natural}$ \\
\hline Dry matter, $\mathrm{g} \mathrm{kg}^{-1}$ & 239 & 236 & 869 & 870 \\
\hline Ash, $\mathrm{g} \mathrm{kg}^{-1}$ of DM & 87 & 71 & 69 & 83 \\
\hline Crude protein, $\mathrm{g} \mathrm{kg}^{-1}$ of DM & 155 & 146 & 202 & 303 \\
\hline Ether extract, $\mathrm{g} \mathrm{kg}^{-1}$ of DM & 50 & 45 & 62 & 87 \\
\hline NDF, $\mathrm{g} \mathrm{kg}^{-1}$ of DM & 506 & 532 & 206 & 243 \\
\hline$M E, M^{k g}{ }^{-1}$ of $D M$ & 10.6 & 11.2 & 12.9 & 12.9 \\
\hline
\end{tabular}

$\mathrm{DM}=$ Dry matter; NDF = Neutral detergent fibre; ME = Metabolizable energy; ${ }^{\dagger}$ Grass silage fed during the dry period $(\mathrm{pH} 4.48$, lactic acid 38 $\mathrm{g} \mathrm{kg}^{-1}$ of DM, acetic acid $11 \mathrm{~g} \mathrm{~kg}^{-1}$ of DM, butyric acid $0.12 \mathrm{~g} \mathrm{~kg}^{-1}$ of DM, ethanol $5.0 \mathrm{~g} \mathrm{~kg}^{-1}$ of DM, water-soluble carbohydrates $100 \mathrm{~g}$ kg-1 of $\mathrm{DM}, \mathrm{NH}_{3}-\mathrm{N} 91 \mathrm{~g} \mathrm{~kg}^{-1}$ of $\mathrm{N}$ ); ${ }^{\ddagger}$ Grass silage fed during lactation ( $\mathrm{pH} 3.96$, lactic acid $40 \mathrm{~g} \mathrm{~kg}^{-1}$ of DM, acetic acid $15 \mathrm{~g} \mathrm{~kg}{ }^{-1}$ of DM, butyric acid 1.8

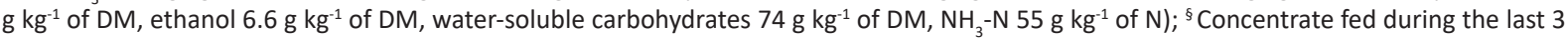
weeks of pregnancy and during lactation, composition in DM ( $\mathrm{g} \mathrm{kg}^{-1}$ of DM): barley 276, rapeseed cake and meal 200, wheat 120 , molassed beet pulp 80 , soybean meal 51, barley malt feed 50 , molasses 45 , hulled oats 40 , dried brewers grain 38 , wheat feed meal 36 , wheat bran 20 , vegetable oil mix 17, calcium carbonate 11 , salt 6.7 , magnesium oxide 3.5 , premixes 2.5 , sodium bicarbonate 2.0 , biotin premix 1.0 ; ${ }^{9}$ Protein supplement fed during lactation, composition in DM ( $\mathrm{g} \mathrm{kg}^{-1}$ of DM): rapeseed cake and meal 508, molassed beet pulp 170, soybean meal 140, wheat feed meal 58 , molasses 45 , barley malt feed 20 , protected fat 20 , propylene glycol premix 14 , vegetable oil mix 12 , salt 6.5 , premixes 4.5 , biotin premix 2.0 .

\section{Sampling, chemical analysis and measurements}

Feed offered and that refused was recorded daily. The feeds were sampled weekly, and the concentrate and silage samples were pooled to form a monthly sample. Feed samples were analyzed as described by Salin et al. (2012). Volatile fatty acid concentration of silage were determined by gas chromatography as detailed by Koivunen et al. (2015).

During the first two weeks of lactation, when kept in tie stalls, the cows were milked twice daily at 0630 and $1700 \mathrm{~h}$. During lactation weeks 3 to 8, the cows were milked with an automated milking system (Lely Astronaut A3, Lely Industries N.V., Maassluis, the Netherlands), and the yield was recorded for every milking. Samples were taken on 4 consecutive milkings, at 1, 2, 4 and 6 weeks after parturition, and treated with preservative (Bronopol, Valio Ltd, Helsinki, Finland). The samples were sent to a commercial laboratory (Valio Ltd., Seinäjoki, Finland) for determination of fat, protein, lactose, and urea using infrared procedures (MilkoScan 605 analyzer; Foss Electric A/S, Hillerød, Denmark).

Body weights were recorded at the same time of day, starting at $1300 \mathrm{~h}$, on two consecutive days, at 6, 4, 2 and 1 weeks before the expected calving date, on the day of calving, the following day, and at 1, 2, 4, 6 and 8 weeks after calving. Body condition scoring (5-point scale; Edmonson et al. 1989) was assessed by the same person throughout the experiment at the same times as weighing.

Blood samples were collected at 42, 28, 21, 14, 8, 5, 3 and $1 \mathrm{~d}$ before the expected calving date and at 1, 3, 5, $7,15,21,28$ and $42 \mathrm{~d}$ after calving. The blood sampling was performed by puncture of the coccygeal vein or artery using evacuated collection tubes (Vacutainer, BD Medical, New Jersey, USA) containing K2-EDTA and placed on ice. Blood samples were centrifuged at $2220 \mathrm{x}$ g for $10 \mathrm{~min}$ to separate the plasma which was then stored at $-20{ }^{\circ} \mathrm{C}$. Plasma glucose, NEFA, $\beta$-hydroxybutyrate (BHBA), insulin and glucagon were measured as described by Selim et al. (2014), and 3-methylhistidine (3-MH) as described by Lamminen et. al. 2017.

\section{Calculations and statistical analyses}

The ME concentration of the silages were calculated based on D-value and ME concentration of cereal concentrate and protein supplement based on feed tables (Luke 2018). The energy requirements (MJ $\mathrm{d}^{-1}$ ) for maintenance, pregnancy, and ECM production were calculated according to Luke (2018), while ECM was calculated according to Sjaunja et al. (1991). The energy balance (EB) was calculated as the difference between the ME intake and the $\mathrm{ME}$ requirements. A correction equation for associative effects of feeds and feeding level was used when ME intake was calculated (Luke 2018).

Two cows, one from each treatment group, were excluded from statistical analysis of postpartum data, due to health problems. One cow suffered from sciatic nerve paralysis, and the other was excluded as a result of prolonged inappetence. 
Data for feed intake, milk production, and blood samples were analyzed as repeated measures ANOVA using the Mixed procedure of SAS version 9.3 (SAS Institute, Cary, NC, USA). Pre- and postpartum periods were analyzed separately. Measurements from DMI, EB, and milk production were reduced to weekly means before statistical analysis. The statistical model included the fixed effects of the treatment, time (the day or week relative to calving), interactions between treatment and time, and a random effect of block and interaction between block and time. Degrees of freedom were estimated by using the Kenward-Roger option in the model statement. For each variable analyzed, a cow nested within the treatment was subjected to 3 covariance structures: compound symmetry, unstructured, and autoregressive order 1 (AR[1]). For unequally spaced measures, spatial power was used instead of $A R(1)$. The covariance structure that minimized the Schwarz Bayesian criterion was used. Prepartal plasma concentrations of 3-MH and glucagon, and the concentration of BHBA postpartum were not normally distributed and were log-transformed prior to statistical analysis. Body weight and BCS data were analyzed with the PROC MIXED procedure with a model that included the fixed effect of treatment and the random effect of block. Treatment effects were considered significant at $p<0.05$, and tendencies of treatment effects were declared at $0.05 \leq p<0.10$.

\section{Results}

The effect of treatment on prepartum feed intake is shown in Table 2 and Fig. 1. Silage DMI was $42 \%$ and ME intake $44 \%$ higher for $\mathrm{HEI}$ than CON cows during the first half of the dry period $(p<0.001)$. The slightly lower ME intake of $\mathrm{HEI}$ relative to target was due to smaller grass silage intake than expected. Corresponding differences of silage DMI and ME intakes were $18 \%$ and $19 \%$ during the last 3 weeks of pregnancy. The EB of CON was slightly positive prepartum, while that of HEI was more positive during the entire dry period, and no differences were observed after calving (Fig. 2). The pre-calving diet did not alter silage or total DMI after calving.

Table 2. Effect of prepartum dietary energy allowance on feed intake of dairy cows for 6 weeks prior to and 8 weeks after calving

\begin{tabular}{|c|c|c|c|c|c|}
\hline & & & & \multicolumn{2}{|c|}{$p$-value } \\
\hline & $\mathrm{CON}^{+}$ & $\mathrm{HEI}^{\ddagger}$ & SEM & Energy level & Energy level $\times$ Week \\
\hline \multicolumn{6}{|l|}{ Prepartum, weeks -6 to -4} \\
\hline Silage $\mathrm{DM}, \mathrm{kg} \mathrm{d}^{-1}$ & 8.9 & 12.6 & 0.26 & $<0.001$ & 0.76 \\
\hline $\mathrm{ME}, \mathrm{MJ} \mathrm{d}^{-1}$ & 99 & 141 & 3.3 & $<0.001$ & 0.91 \\
\hline $\mathrm{CP}, \mathrm{g} \mathrm{d}^{-1}$ & 1414 & 2007 & 53.2 & $<0.001$ & 0.79 \\
\hline $\mathrm{NDF}, \mathrm{g} \mathrm{d}^{-1}$ & 4531 & 6515 & 117.6 & $<0.001$ & 0.78 \\
\hline \multicolumn{6}{|l|}{ Prepartum, weeks -3 to -1} \\
\hline Silage DM, $\mathrm{kg} \mathrm{d}^{-1}$ & 7.3 & 8.6 & 0.18 & $<0.001$ & 0.04 \\
\hline Total DM, kg d ${ }^{-1}$ & 9.7 & 11.5 & 0.15 & $<0.001$ & $<0.001$ \\
\hline $\mathrm{ME}, \mathrm{MJ} \mathrm{d}^{-1}$ & 109 & 128 & 1.8 & $<0.001$ & $<0.001$ \\
\hline$C P, g^{-1}$ & 1556 & 1871 & 30.3 & $<0.001$ & $<0.001$ \\
\hline $\mathrm{NDF}, \mathrm{g} \mathrm{d}^{-1}$ & 4137 & 4921 & 82.6 & $<0.001$ & 0.002 \\
\hline \multicolumn{6}{|l|}{ Postpartum } \\
\hline Silage DM, $\mathrm{kg} \mathrm{d}^{-1}$ & 10.1 & 10.7 & 0.56 & 0.31 & 0.63 \\
\hline Concentrate DM, kg d ${ }^{-1}$ & 12.6 & 12.1 & 0.16 & 0.03 & 0.78 \\
\hline Total DM, kg d $\mathrm{d}^{-1}$ & 22.7 & 22.8 & 0.64 & 0.85 & 0.64 \\
\hline $\mathrm{ME}, \mathrm{MJ} \mathrm{d}^{-1}$ & 254 & 253 & 6.2 & 0.94 & 0.58 \\
\hline $\mathrm{CP}, \mathrm{g} \mathrm{d}^{-1}$ & 4223 & 4235 & 103.7 & 0.89 & 0.62 \\
\hline $\mathrm{NDF}, \mathrm{g} \mathrm{d}^{-1}$ & 7853 & 8009 & 309.0 & 0.65 & 0.71 \\
\hline
\end{tabular}

$\mathrm{DM}=$ Dry matter; $\mathrm{ME}=$ Metabolizable energy; $\mathrm{CP}=$ Crude protein; NDF $=$ Neutral detergent fibre; ${ }^{+} \mathrm{CON}=100 \%$ of $\mathrm{ME}$ requirements for the whole dry period; ${ }^{\ddagger} \mathrm{HEI}=144 \%$ of $\mathrm{ME}$ requirements during the far-off dry period, combined with gradually decreased energy allowance during the last 3 weeks of gestation (average ME intake $119 \%$ of requirements) 


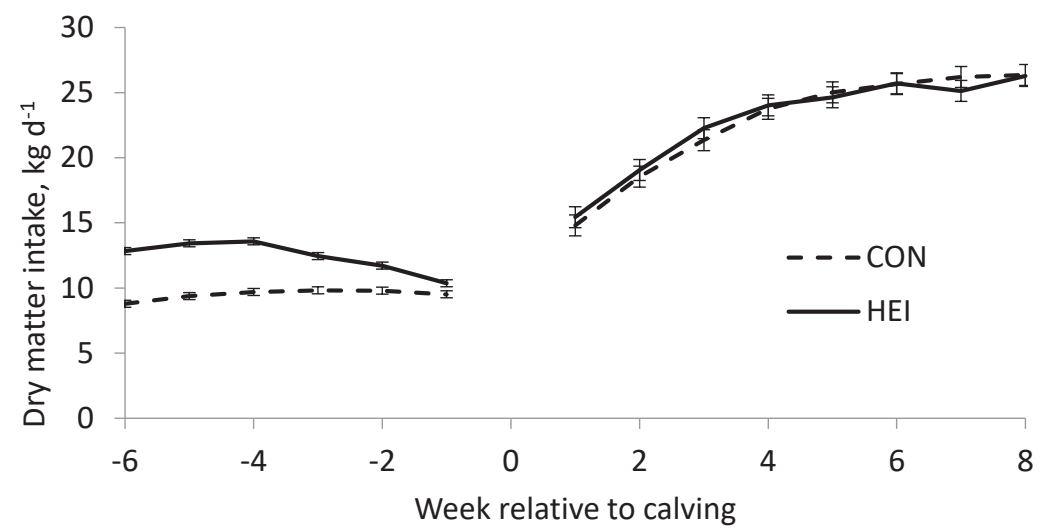

Fig. 1. Dry matter intake of cows offered two levels of energy intake prepartum, $\mathrm{HEI}=144 \%$ of ME requirements during weeks 6 to 4 prepartum, and $119 \%$ of ME requirements during weeks 3 to 1 prepartum (gradual decrease of energy allowance); and CON $100 \%$ of ME requirements during the dry period. Pooled SEM prepartum $0.19 \mathrm{~kg} \mathrm{DM} \mathrm{d}^{-1}$ and postpartum $0.64 \mathrm{~kg} \mathrm{DM} \mathrm{d}^{-1}$. Error bars represent SEM at individual time points. Significant effect of treatment $(p<0.001)$ and treatment $\times$ time $(p<$ 0.001 ) for prepartum data.

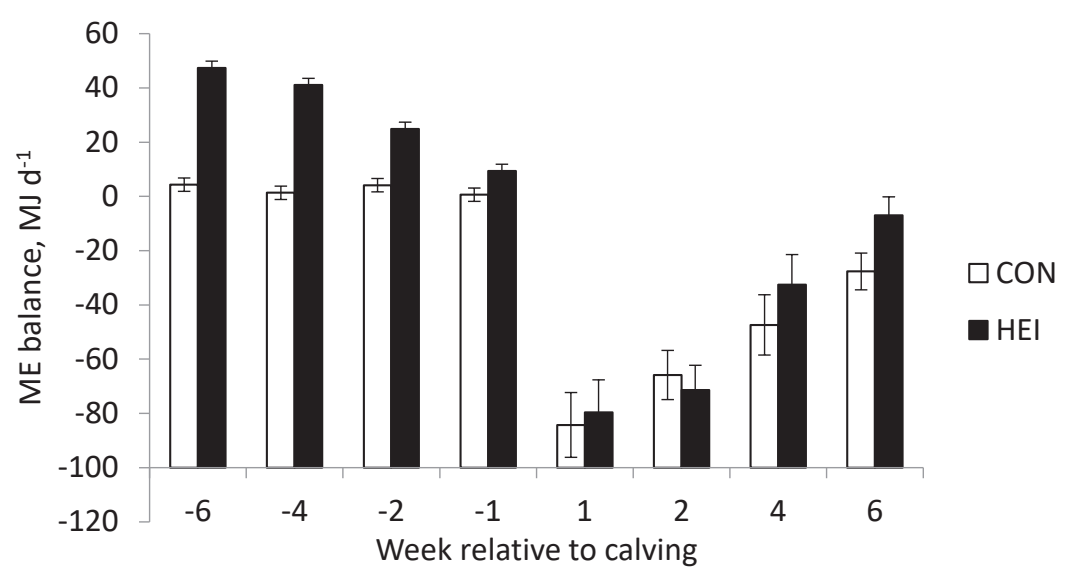

Fig. 2. Metabolizable energy balance of cows offered two levels of energy intake prepartum, $\mathrm{HEI}=144 \%$ of ME requirements during weeks 6 to 4 prepartum, and $119 \%$ of ME requirements during weeks 3 to 1 prepartum (gradual decrease of energy allowance); and CON $100 \%$ of ME requirements during the dry period. Pooled SEM prepartum $1.5 \mathrm{MJ} \mathrm{d}^{-1}$ and postpartum 7.9 $\mathrm{MJ} \mathrm{d}^{-1}$. Error bars represent SEM at individual time points. Significant effect of treatment $(p<0.001)$ and treatment $\times$ time $(p<0.001)$ for prepartum data.

The effects of the treatment on early lactation performance are presented in Table 3. The average milk yield tended to be lower for HEI $(p=0.08)$, and there was a tendency for treatment $\times$ time interaction $(p=0.09)$ (Fig. 3$)$.

Table 3. Effect of prepartum dietary energy allowance on milk production of dairy cows during weeks 1 to 8 of lactation

\begin{tabular}{|c|c|c|c|c|c|}
\hline & & & & \multicolumn{2}{|c|}{$p$-value } \\
\hline & $\operatorname{CON}^{*}$ & $\mathrm{HEI}^{+}$ & SEM & Energy level & Energy level $\times$Week \\
\hline Milk, kg d ${ }^{-1}$ & 44.3 & 40.5 & 1.69 & 0.08 & 0.09 \\
\hline $\mathrm{ECM}, \mathrm{kg} \mathrm{d}^{-1 \neq}$ & 42.7 & 41.2 & 1.72 & 0.42 & 0.14 \\
\hline Fat, $\mathrm{g} \mathrm{kg}^{-1}$ & 46.2 & 47.0 & 0.12 & 0.61 & 0.61 \\
\hline Protein, $\mathrm{g} \mathrm{kg}^{-1}$ & 33.6 & 35.1 & 0.08 & 0.12 & 0.22 \\
\hline Lactose, $\mathrm{g} \mathrm{kg}^{-1}$ & 46.1 & 45.4 & 0.02 & 0.02 & 0.48 \\
\hline Urea, mg dl-1 & 24.1 & 23.9 & 1.49 & 0.93 & 0.43 \\
\hline Fat yield, $\mathrm{g} \mathrm{d}^{-1}$ & 1852 & 1770 & 83.7 & 0.50 & 0.01 \\
\hline Protein yield, $\mathrm{g} \mathrm{d}^{-1}$ & 1321 & 1334 & 61.1 & 0.77 & 0.02 \\
\hline Lactose yield, $\mathrm{g} \mathrm{d}^{-1}$ & 1885 & 1737 & 76.4 & 0.22 & 0.11 \\
\hline
\end{tabular}

$\mathrm{CON}=100 \%$ of $\mathrm{ME}$ requirements for the whole dry period; $+\mathrm{HEI}=144 \%$ of $\mathrm{ME}$ requirements during the far-off dry period, combined with gradually decreased energy allowance during the last 3 weeks of gestation (average ME intake 119\% of requirements); ECM = Energy corrected milk 


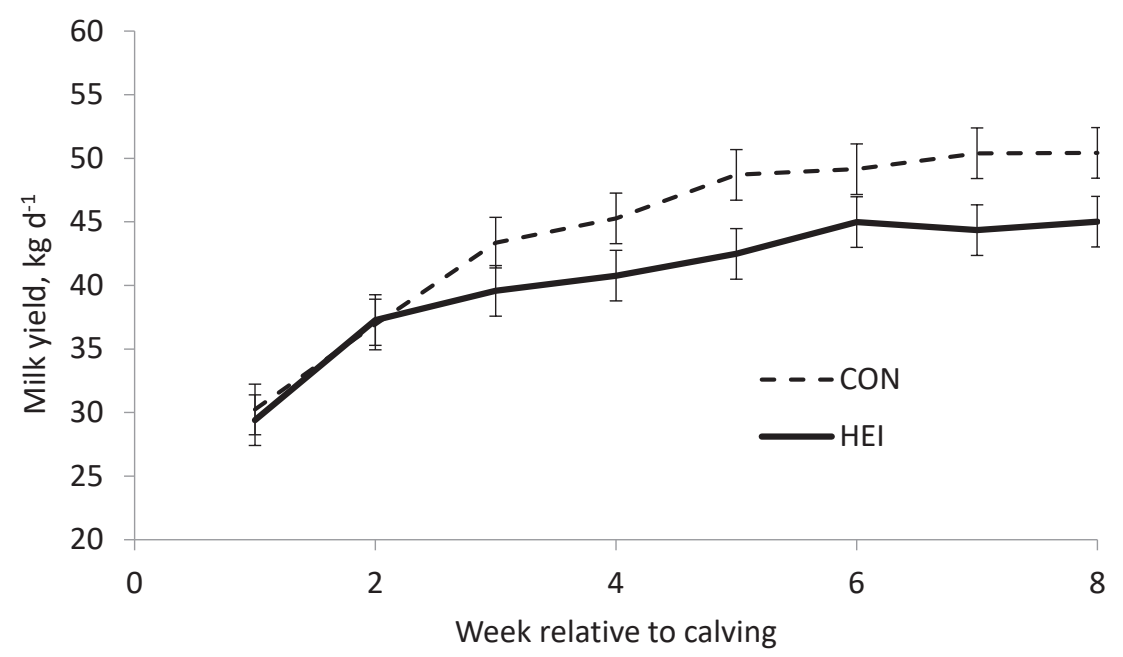

Fig. 3. Milk yield of cows offered two levels of energy intake prepartum, $\mathrm{HEI}=144 \%$ of ME requirements during weeks 6 to 4 prepartum, and $119 \%$ of ME requirements during weeks 3 to 1 prepartum (gradual decrease of energy allowance); and CON $=100 \%$ of ME requirements during the dry period. Pooled SEM $1.69 \mathrm{~kg} \mathrm{~d}^{-1}$. Error bars represent SEM at individual time points. Tendency for treatment effect $(p=0.08)$ and treatment $\times$ time $(p=0.09)$.

HEI had lower milk yield than CON at lactation weeks 5,7 and $8(p<0.05)$, and tended to have lower milk yield $(p=0.09)$ at week 4 postpartum. The fat, protein, and urea concentration of milk was not affected by the treatment. HEI had lower lactose concentration than CON $(p<0.05)$. Average fat, protein, lactose, and ECM yields did not differ between treatments. Fat yield for HEl at lactation week 6 was lower and protein yield was higher at lactation week 2 ( $p<0.05$; treatment $\times$ time interaction).

There were no differences in gestation lengths. On average, cows in CON calved $2 \mathrm{~d}( \pm 5.4)$ and cows in HEI $3 \mathrm{~d}$ $( \pm 5.3)$ after the due date. The BCS of both groups increased slightly during the dry period (Table 4). Body weight gains of HEI and CON were similar, whereas calf weight tended to be lower in HEI than in CON $(p=0.08)$. There was a strong positive association between BCS at $-42 d$ and at $-5 d$ across the treatments $\left(r^{2}=0.82\right)$. After calving, the treatment had no effect on BW or BCS changes.

Table 4. Effect of prepartum dietary energy allowance on body condition score and body weight of dairy cows for 6 weeks prior to and 8 weeks after calving

\begin{tabular}{|c|c|c|c|c|}
\hline & $\mathrm{CON}^{*}$ & $\mathrm{HEI}^{+}$ & SEM & $p$-value \\
\hline \multicolumn{5}{|l|}{ Prepartum } \\
\hline Body condition score, -6 weeks & 3.7 & 3.6 & 0.10 & 0.33 \\
\hline Body condition score, -1 week & 3.8 & 3.7 & 0.14 & 0.61 \\
\hline Body weight, -6 weeks, kg & 694 & 692 & 20.8 & 0.94 \\
\hline Body weight, -1 week, kg & 727 & 738 & 24.3 & 0.71 \\
\hline Body weight change, kg d-1 & 1.1 & 1.3 & 0.18 & 0.28 \\
\hline Calf weight, kg & 47.0 & 40.7 & 2.25 & 0.08 \\
\hline \multicolumn{5}{|l|}{ Postpartum } \\
\hline Body condition score, +8 weeks & 2.7 & 2.8 & 0.17 & 0.83 \\
\hline Body weight, +1 day, $\mathrm{kg}$ & 655 & 681 & 20.8 & 0.41 \\
\hline Body weight, +8 weeks, $\mathrm{kg}$ & 632 & 650 & 18.9 & 0.50 \\
\hline Body weight change, $\mathrm{kg} \mathrm{d}-1$ & -0.4 & -0.6 & 0.17 & 0.34 \\
\hline
\end{tabular}

${ }^{\circ} \mathrm{CON}=100 \%$ of ME requirements for the whole dry period; ${ }^{+} \mathrm{HEI}=144 \%$ of ME requirements during far-off dry period, combined with gradually decreased energy allowance during the last 3 weeks of gestation (average ME intake 119\% of requirements) 
The HEl cows had lower concentrations of NEFA in plasma throughout the dry period $(p<0.05)$ than CON cows (Table 5). Plasma glucose concentrations were unaffected. Before calving, insulin concentration tended to be higher in HEI than in CON ( $p=0.09$; Fig. 4). Mean plasma BHBA was similar in both treatments, but a tendency for treatment $\times$ time interaction $(p=0.09)$ showed a delayed increase of BHBA concentrations in HEI during the last days of pregnancy. The treatment did not affect plasma concentrations of glucose, NEFA, insulin, glucagon, and BHBA after calving. Plasma 3-MH concentration tended to be lower for HEI than CON after calving $(p=0.07)$.

Table 5. Effect of prepartum dietary energy allowance on blood composition of dairy cows for 6 weeks prior to and 8 weeks after calving

\begin{tabular}{|c|c|c|c|c|c|}
\hline & \multirow[b]{2}{*}{$\mathrm{CON}^{+}$} & \multirow[b]{2}{*}{$\mathrm{HEI}^{\ddagger}$} & \multirow[b]{2}{*}{ SEM } & \multicolumn{2}{|c|}{$p$-value } \\
\hline & & & & Energy level & Energy level $\times$ Week \\
\hline \multicolumn{6}{|l|}{ Prepartum } \\
\hline Glucose, $\mathrm{mmol} \mathrm{l}^{-1}$ & 4.4 & 4.3 & 0.09 & 0.24 & 0.81 \\
\hline NEFA, mmol l-1 & 0.24 & 0.18 & 0.019 & 0.03 & 0.81 \\
\hline BHBA, mmol l-1 & 0.88 & 0.78 & 0.054 & 0.11 & 0.09 \\
\hline $\log 3-\mathrm{MH}, \mu \mathrm{mol} \mathrm{I} \mathrm{I}^{-1 \S}$ & $2.77(6.82)$ & $2.67(6.36)$ & 0.091 & 0.33 & 0.15 \\
\hline Insulin, $\mu \mathrm{IU} \mathrm{ml^{-1 }}$ & 15.9 & 24.2 & 3.34 & 0.09 & 0.88 \\
\hline Log Glucagon, pg ml-1§ & $2.07(117.5)$ & $2.16(144.5)$ & 0.055 & 0.22 & 0.24 \\
\hline Glucagon:insulin, $\mathrm{mol} \mathrm{mol}^{-1}$ & 0.29 & 0.26 & 0.027 & 0.46 & 0.41 \\
\hline \multicolumn{6}{|l|}{ Postpartum } \\
\hline Glucose, $\mathrm{mmol} \mathrm{l}^{-1}$ & 3.4 & 3.3 & 0.13 & 0.51 & 0.35 \\
\hline NEFA, mmol I-1 & 0.49 & 0.46 & 0.045 & 0.63 & 0.42 \\
\hline Log BHBA, mmol l-1§ & $0.55(1.47)$ & $0.59(1.50)$ & 0.246 & 0.87 & 0.45 \\
\hline 3-MH, $\mu \mathrm{mol} \mathrm{I}^{-1}$ & 8.66 & 7.89 & 0.558 & 0.07 & 0.57 \\
\hline Insulin, $\mu \mathrm{IU} \mathrm{ml}^{-1}$ & 8.6 & 11.1 & 2.70 & 0.52 & 0.21 \\
\hline Glucagon, $\mathrm{pg} \mathrm{ml}^{-1}$ & 153.0 & 142.1 & 12.94 & 0.46 & 0.55 \\
\hline Glucagon:insulin, mol mol-1 & 0.99 & 0.88 & 0.209 & 0.67 & 0.19 \\
\hline
\end{tabular}

NEFA = non-esterified fatty acids; $\mathrm{BHBA}=$ betahydroxybutyrate; $3-\mathrm{MH}=3$-methylhistidine; ${ }^{\dagger} \mathrm{CON}=100 \%$ of $\mathrm{ME}$ requirements for the whole dry period; ${ }^{\ddagger} \mathrm{HEI}=144 \%$ of $\mathrm{ME}$ requirements during the far-off dry period, combined with gradually decreased energy allowance during the last 3 weeks of gestation (average ME intake $119 \%$ of requirements); ${ }^{\S}$ Non-transformed means are presented in parenthesis

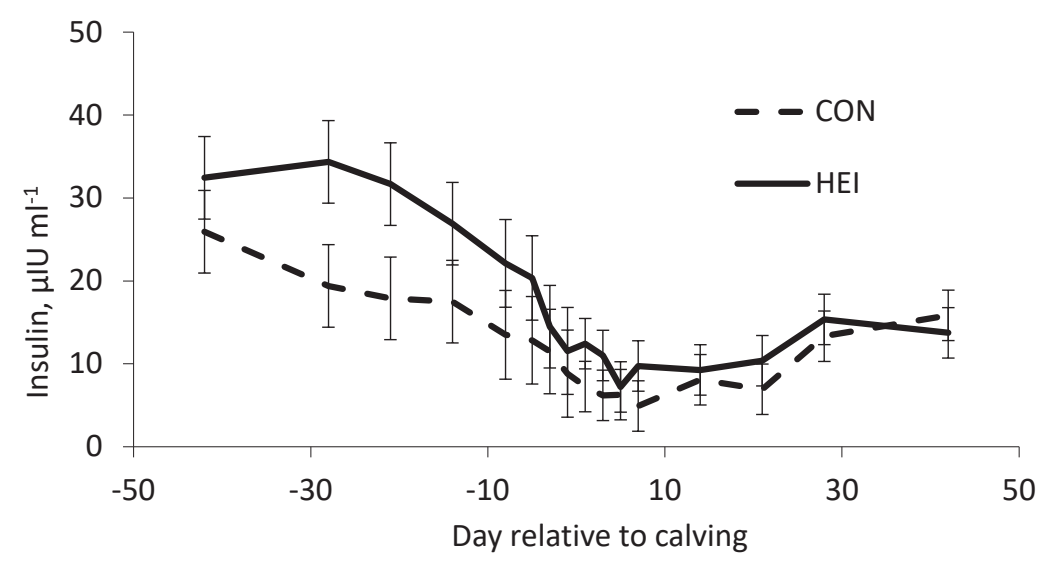

Fig. 4. Plasma insulin concentration of cows offered two levels of energy intake prepartum, $\mathrm{HEI}$ $=144 \%$ of $\mathrm{ME}$ requirements during weeks 6 to 4 prepartum, and $119 \%$ of ME requirements during weeks 3 to 1 prepartum (gradual decrease of energy allowance); and CON = 100\% of $\mathrm{ME}$ requirements during the dry period. Pooled SEM prepartum $3.34 \mu \mathrm{IU} \mathrm{ml}{ }^{-1}$, postpartum $2.70 \mu \mathrm{IU} \mathrm{ml}{ }^{-1}$. Error bars represent SEM at individual time points. Tendency for treatment effect $(p=0.09)$ for prepartum data. 


\section{Discussion}

In the present study, the cows were offered a high or a controlled allowance of GS during the FODP, and concentrate was included in the diet during the CUDP. Previously, a dry cow's El has been modified by increasing the daily concentrate allowance or the concentrate proportion of the diet, or by adding high fiber feeds (e.g. straw) to the diet (Remppis et al. 2011). On some occasions, an increased concentrate allowance has been extended over the whole dry period, or even beyond, to achieve large differences in the BCS (e.g. Agenäs et al. 2003). These reports have demonstrated the potentially negative effects of over-conditioning at calving on feed intake and milk production performance during early lactation.

\section{Feed intake}

The HEI cows were forced to decrease DMI by gradually decreasing their energy allowance. This approach was applied in order to study the potential effect of a prepartal change of feed intake on the metabolism of the cows, as voluntary DMI may decrease by 30 to 50\% during the last 2 to 3 weeks of pregnancy (Grummer et al. 2004). The achieved magnitude of the decline in DMI was 30\% between weeks 4 and 1 prepartum while the treatment did not affect silage or total DMI postpartum. Therefore, it seems unlikely that the drop in DMI pre-calving per se would be a factor that affects DMI during the early weeks of lactation in GS-based diets. More importantly, all the cows in $\mathrm{HEl}$ remained in positive EB during the period of decreasing feed allowance indicating that these cows did not reduce their feed intake more than they were forced to do.

The lack of treatment effect on postpartum total DMI contrasts with earlier work suggesting that high DMI (150 to $180 \%$ of energy requirements) in late pregnancy is associated with lower DMI during early lactation (Agenäs et al. 2003, Douglas et al. 2006, Janovick and Drackley 2010). Our results imply that moderate overfeeding of energy ( 30 to $40 \%$ ) during the FODP or during the entire dry period had no effect on postpartum DMI, identically to earlier studies on GS (Keady et al. 2005, Kokkonen et al. 2005, Salin et al. 2018).

\section{Milk yield}

There were no effects of dry period feeding on ECM or milk component yields during lactation weeks 1 to 6 , in accordance with earlier studies by Agenäs et al. (2003) and Little et al. (2016). The tendency for lower milk yield in HEI than in CON cows from week 4 onwards is consistent with the study by Tesfa et al. (1999), which showed that increasing the El of dry cows with concentrate tended to decrease milk yield in GS-based diets. In contrast, other studies reported no effect of dry period El on milk yield on GS-based diets (Keady et al. 2001, Kokkonen et al. 2005, Little et al. 2016). In trials showing the positive effects of controlled El during the dry period on postpartum DMI, no effect on milk yield was reported (Dann et al. 2006, Douglas et al. 2006, Janovick and Drackley 2010).

\section{Lipid reserves}

A high El during the dry period tended to increase prepartum plasma insulin concentration, which is consistent with earlier studies showing that high El during the whole dry period (Holtenius et al. 2003, Salin et al. 2018) or during the CUDP (Cardoso et al. 2013) increased circulating insulin levels, reflecting positive EB. The lower insulin concentration in CON facilitated the increase in plasma NEFA before calving concordantly with others (Douglas et al. 2006, Salin et al. 2018). The lower prepartal NEFA of the HEI suggests increased lipid deposition in adipose tissue prepartum. However, the BW and BCS of CON and HEI did not differ. HEI cows tended to have lighter calves than CON cows, which may have masked some of the difference in maternal weight gain. Lighter calves in HEI were unexpected, since earlier studies have reported that prepartum El had no effect on calf weight when the energy allowance is from 75 to $150 \%$ of requirements (Tesfa et al. 1999, Douglas et al. 2006, Janovick and Drackley 2010).

The small differences in BW gains between the treatments may be due to the feeding of a solely GS diet during the FODP. The effect of a high-energy high-forage diet on blood insulin and hence stimulation of tissue deposition may be smaller than the effect of a diet with an increased concentrate proportion. Increasing the concentrate ratio in the dry cow diet may elevate blood insulin, even in the absence of differences in ME intake (Holcomb et al. 2001, Kokkonen et al. 2004).

The lack of difference in BCS changes pre-calving was probably partly due to the lack of sensitivity of the condition scoring system. As pointed out earlier by others, the estimation of the variation of visceral fat mass is beyond detection of the current method for assessment of BCS, and may bias the interpretation of treatment effects on 
adipose tissue accretion (Drackley et al. 2014). Moreover, large changes in BCS are difficult to achieve during the standard dry period of 6-8 weeks. The observed strong positive association between BCS at $-42 \mathrm{~d}$ and at $-5 \mathrm{~d}$ across the treatments is in agreement with a reported strong correlation between BCS at drying off and at calving (Friggens et al. 2004, Salin et al. 2018). Increasing the energy allowance of cows by increasing the TMR allowance or energy content, or by the inclusion of concentrate in a GS-based diet during the dry period has resulted in a moderate rise in BCS (e.g. Kokkonen et al. 2005, Douglas et al. 2006, Salin et al. 2018). In the current study, a high initial BCS may have contributed to the lack of treatment effect on BCS. Accordingly, when the initial BCS was 3.5 or more, prepartal El had no effect on BCS (Tesfa et al. 1999, Winkelman et al. 2008). In contrast, a more liberal energy intake (71, 106 or $177 \mathrm{MJ} \mathrm{d}^{-1}$ ) of GS-based diets induced larger changes in BCS during the 8-week dry period, although the initial BCS of cows was high i.e. 3.5 to 3.7 (Agenäs et al. 2003).

\section{Mobilization of tissue reserves}

There were no differences in NEFA concentration after calving, which is in accordance with Tesfa et al. (1999) and Winkelman et al. (2008). Larger BW and BCS gains during the dry period have resulted in increased lipid mobilization as indicated by higher plasma NEFA concentrations after calving in cows fed high-energy diets prepartum (Holtenius et al. 2003, Kokkonen et al. 2005, Douglas et al. 2006). The fact that we decreased the El of HEl cows in CUDP may have diminished adverse effects on mobilization of body reserves. Nevertheless, the high-energy feeding still increased the average energy allowance by $30 \%$ compared with CON. In line with present results, Salin et al. (2018) found no differences in BCS and BW changes after parturition in cows with ad libitum GS (141\% of ME requirement) vs. cows fed a mixture of GS and wheat straw (108\% of ME requirement) during the dry period. It should be noted that lipolytic activity after calving may differ between breeds (Theilgaard et al. 2002), and also genetic strain may affect lipid mobilization (Roche et al. 2009). Thus, genetic factors modulate the effects of dry period nutrition on the use of energy reserves and complicate the comparison of the results from different studies.

Consistent with several other studies (e.g. Holtenius et al. 2003, Salin et al. 2018) prepartal El had no effect on insulin concentration postpartum. As opposed to our results, a pooled analysis of seven studies (Cardoso et al. 2013) showed that cows fed high energy in FODP had lower insulin concentrations during the first two weeks of lactation than cows fed controlled energy diets. Holtenius et al. (2003) suggested that high El during the dry period induced a greater degree of insulin resistance after calving, giving rise to a more pronounced lipolysis from the adipose tissue. Based on an intravenous glucose tolerance tests, this was not observed in the cows of the current study, as reported in a companion paper by Salin et al. (2017). On the contrary, the HEI cows were more sensitive to antilipolytic action of insulin in than CON cows $10 \mathrm{~d}$ after parturition (Salin et al. 2017).

The lack of differences in plasma NEFA and BHBA concentrations after calving agrees with others (Tesfa et al. 1999, Holtenius et al. 2003) and suggest that El before calving had no effect on the use of NEFA and BHBA as energy-yielding substrates to spare glucose after calving. However, others (Kokkonen et al. 2005, Douglas et al. 2006) reported greater postpartal BHBA concentrations in association with dry period overfeeding. The absence of effect on plasma BHBA and liver lipid concentration suggests that the dry period El had no major effect on hepatic fatty acid oxidation capacity, although $\mathrm{HEl}$ cows had a lower hepatic gene expression of the key enzyme controlling the entry of NEFA into mitochondria for $\beta$-oxidation in the transition period as reported in companion paper by Selim et al. (2014). The higher plasma concentration of 3-MH in CON indicates increased amino acid mobilization after calving. Cows in CON may have used more mobilized amino acids, especially alanine, for hepatic gluconeogenesis. Indeed, Selim et al. (2014) observed that CON cows had higher hepatic gene expression of pyruvate carboxylase, promoting the entry of endogenous substrates (amino acids, lactate) for gluconeogenesis (Aschenbach et al. 2010).

\section{Conclusions}

High intake of GS had only a minor effect on BW gain during the dry period, and did not affect the mobilization of tissue reserves after calving, compared with feeding according to energy requirements. A lower plasma NEFA concentration in high-energy fed cows during the dry period suggests enhanced lipid deposition in adipose tissue, facilitated by higher plasma insulin. Feeding a high-energy diet during the dry period tended to decrease the milk yield but did not alter ECM or DMI after calving. Based on the current results, we conclude that the gradual decline of feed intake during the last 3 weeks of pregnancy, combined with a high initial energy allowance, does not affect DMI or lipid mobilization during the early weeks of lactation in a GS-based diet. 


\section{Acknowledgements}

This study was funded by the Ministry of Agriculture and Forestry, Finland. The second author was financially supported by Raisio plc Research Foundation (Raisio, Finland). The authors thank Pirjo Pursiainen, Juha Suomi and the staff at the research farm of the University of Helsinki for the care of the experimental animals. The authors also extend thanks to the laboratory staff of the Department of Agricultural Sciences, University of Helsinki.

\section{References}

Agenäs, S., Burstedt, E. \& Holtenius, K. 2003. Effects of feeding intensity during the dry period. 1. Feed intake, body weight, and milk production. Journal of Dairy Science 86: 870-882. https://doi.org/10.3168/jds.S0022-0302(03)73670-4

Allen, M.S., Bradford, B.J. \& Oba, M. 2009. The hepatic oxidation theory of the control of feed intake and its application to ruminants. Journal of Animal Science 87: 3317-3334. https://doi.org/10.2527/jas.2009-1779

Aschenbach, J.R., Kristensen, N.B., Donkin, S.S., Hammon, H.M. \& Penner, G.B. 2010. Gluconeogenesis in dairy cows: the secret of making sweet milk from sour dough. IUBMB Life 62: 869-877. https://doi.org/10.1002/iub.400

Cardoso, F.C., LeBlanc, S.J., Murphy, M.R. \& Drackley, J.K. 2013. Prepartum nutritional strategy affects reproductive performance in dairy cows. Journal of Dairy Science 96: 5859-5871. https://doi.org/10.3168/jds.2013-6759

Dann, H.M., Litherland, N.B., Underwood, J.P., Bionaz, M., D’Angelo, A., McFadden, J.W. \& Drackley, J.K. 2006. Diets during far-off and close-up dry periods affect periparturient metabolism and lactation in multiparous cows. Journal of Dairy Science 89: $3563-$ 3577. https://doi.org/10.3168/jds.S0022-0302(06)72396-7

Dewhurst, R.J., Davies, D.W.R. \& Fisher, W.J. 2009. Effects of silage digestibility on intake and body reserves of dry cows and performance in the first part of the next lactation. Animal 3: 1721-1727. https://doi.org/10.1017/S1751731109990632

Douglas, G.N., Overton, T.R., Bateman, II, H.G., Dann, H.M. \& Drackley, J.K. 2006. Prepartal plane of nutrition, regardless of dietary energy source, affects periparturient metabolism and dry matter intake in Holstein cows. Journal of Dairy Science 89: 2141-2157. https://doi.org/10.3168/jds.S0022-0302(06)72285-8

Drackley, J.K., Wallace, R.L., Graugnard, D., Vasquez, J., Richards, B.F. \& Loor, J.J. 2014. Visceral adipose tissue mass in nonlactating dairy cows fed diets differing in energy density. Journal of Dairy Science 97: 3420-3430. https://doi.org/10.3168/jds.2014-8014

Edmonson, A.J., Lean, I.J., Weaver, L.D., Farver, T. \& Webster, G. 1989. A body condition chart of Holstein dairy cows. Journal of Dairy Science 72: 68-78. https://doi.org/10.3168/jds.S0022-0302(89)79081-0

Friggens, N.C., Andersen, J.B., Larsen, T., Aaes, O. \& Dewhurst, R.J. 2004. Priming the dairy cow for lactation: A review of dry cow feeding strategies. Animal Research 53: 453-473. https://doi.org/10.1051/animres:2004037

Grummer, R.R., Mashek, D.G. \& Hayirli, A. 2004. Dry matter intake and energy balance in the transition period. Veterinary Clinics of North America: Food Animal Practice 20: 447-470. https://doi.org/10.1016/j.cvfa.2004.06.013

Holcomb, C.S., Van Horn, H.H., Head, H.H., Hall, M.B. \& Wilcox, C.J. 2001. Effects of prepartum dry matter intake and forage percentage on postpartum performance of lactating dairy cows. Journal of Dairy Science 84: 2051-2058. https://doi.org/10.3168/ jds.S0022-0302(01)74649-8

Holtenius, K., Agenäs, S., Delavaud, C. \& Chilliard, Y. 2003. Effects of feeding intensity during the dry period. 2. Metabolic and hormonal responses. Journal of Dairy Science 86: 883-891. https://doi.org/10.3168/jds.S0022-0302(03)73671-6

Janovick, N.A. \& Drackley, J.K. 2010. Prepartum dietary management of energy intake affects postpartum intake and lactation performance by primiparous and multiparous Holstein cows. Journal of Dairy Science 93: 3086-3102. https://doi.org/10.3168/ jds.2009-2656

Keady, T.W.J., Mayne, C.S., Fitzpatrick, D.A. \& McCoy, M.A. 2001. Effect of concentrate feed level in late gestation on subsequent milk yield, milk composition, and fertility of dairy cows. Journal of Dairy Science 84: 1468-1479. https://doi.org/10.3168/jds. S0022-0302(01)70180-4

Keady, T.W.J., Mayne, C.S., Kilpatrick, D.J. \& McCoy, M.A. 2005. Effect of level and source of nutrients in late gestation on subsequent milk yield and composition and fertility of dairy cows. Livestock Production Science 94: 237-248. https://doi.org/10.1016/j. livprodsci.2004.12.001

Koivunen, E., Jaakkola, S., Heikkilä, T., Lampi, A.M., Halmemies-Beauchet-Filleau, A., Lee, M.R.F., Winters, A.L., Shingfield, K.J. \& Vanhatalo, A. 2015. Effects of plant species, stage of maturity, and level of formic acid addition on lipolysis, lipid content, and fatty acid composition during ensiling. Journal of Animal Science 93: 4408-4423. https://doi.org/10.2527/jas.2014-8813

Kokkonen, T., Taponen, J., Anttila, T., Syrjälä-Qvist, L., Delavaud, C., Chilliard, Y., Tuori, M. \& Tesfa, A.T. 2005. Effect of body fatness and glucogenic supplement on lipid and protein mobilization and plasma leptin in dairy cows. Journal of Dairy Science 88 : 1127-1141. https://doi.org/10.3168/jds.S0022-0302(05)72779-X

Kokkonen, T., Tesfa, A.T., Tuori, M. \& Syrjälä-Qvist, L. 2004. Concentrate feeding strategy of dairy cows during the transition period. Livestock Production Science 86: 239-251. https://doi.org/10.1016/j.livprodsci.2003.09.003

Lamminen, M., Halmemies-Beauchet-Filleau, A., Kokkonen, T., Simpura, I., Jaakkola S. \& Vanhatalo, A. 2017. Comparison of microalgae and rapeseed meal as supplementary protein in the grass silage based nutrition of dairy cows. Animal Feed Science and Techology 234: 295-311. https://doi.org/10.1016/j.anifeedsci.2017.10.002

Little, M.W., O'Connell, N.E., Welsh, M.D., Barley, J., Meade, K.G. \& Ferris, C. P. 2016. Prepartum concentrate supplementation of a diet based on medium-quality grass silage: Effects on performance, health, fertility, metabolic function, and immune function of low body condition score cows. Journal of Dairy Science 99: 7102-7122. https://doi.org/10.3168/jds.2016-11071 
Luke 2018. Feed tables and nutrient requirements, Natural Resources Institute Finland (Luke). Accessed 20 November 2018. https://portal.mtt.fi/portal/page/portal/Rehutaulukot/feed_tables_english

Remppis, S., Steingass, H., Gruber, L. \& Schenkel, H. 2011. Effects of energy intake on performance, mobilization and retention of body tissue, and metabolic parameters in dairy cows with special regard to effects of pre-partum nutrition on lactation - A Review. Asian-Australian Journal of Animal Science 24: 540-572. https://doi.org/10.5713/ajas.2011.10134

Roche, J.R., Friggens, N.C., Kay, J.K., Fisher, M.W., Stafford, K. J. \& Berry, D.P. 2009. Body condition score and its association with dairy cow productivity, health, and welfare. Journal of Dairy Science 92: 5769-5801. https://doi.org/10.3168/jds.2009-2431

Salin, S., Taponen, J., Elo, K., Simpura, I., Vanhatalo, A., Boston, R. \& Kokkonen, T. 2012. Effects of abomasal infusion of tallow or camelina oil on responses to glucose and insulin in dairy cows during late pregnancy. Journal of Dairy Science 95: 3812-3825. https://doi.org/10.3168/jds.2011-5206

Salin, S., Vanhatalo, A., Elo, K., Taponen, J., Boston, R.C. \& Kokkonen, T. 2017. Effects of dietary energy allowance and decline in dry matter intake during the dry period on responses to glucose and insulin in transition dairy cows. Journal of Dairy Science 100: 5266-5280. https://doi.org/10.3168/jds.2016-11871

Salin, S., Vanhatalo, A., Jaakkola, S., Elo, K., Taponen, J., Boston, R.C. \& Kokkonen, T. 2018. Effects of dry period energy intake on insulin resistance, metabolic adaptation, and production responses in transition dairy cows on grass silage-based diets. Journal of Dairy Science 101:11364-11383. https://doi.org/10.3168/jds.2018-14728

Selim, S., Salin, S., Taponen, J., Vanhatalo, A., Kokkonen, T. \& Elo, K. 2014. Effect of prepartal ad libitum feeding of grass silage on transcriptional adaptations of the liver and subcutaneous adipose tissue in dairy cows during the periparturient period. Physiological Genomics 46: 328-337. https://doi.org/10.1152/physiolgenomics.00115.2013

Sjaunja, L.O., Baerve, L., Junkkarinen, L., Pedersen, J. \& Setälä, J. 1991. A Nordic proposal for an energy corrected milk (ECM) formula. In: Gaillon, P. \& Chabert, Y. (eds.). Performance recording of animals: State of the art. EAAP Publication 50. PUDOC, Wageningen, the Netherlands. p. 156-157.

Tesfa, A.T., Tuori, M., Syrjälä-Qvist, L., Pösö, R., Saloniemi, H., Heinonen, K., Kivilahti, K., Saukko, T. \& Lindberg, L.-A. 1999. The influence of dry period feeding on liver fat and postpartum performance of dairy cows. Animal Feed Science and Technology 76 : 275-295. https://doi.org/10.1016/S0377-8401(98)00221-1

Theilgaard, P., Friggens, N.C., Sloth, K.H. \& Ingvartsen, K.L. 2002. The effect of breed, parity and body fatness on the lipolytic response of dairy cows. Animal Science 75: 209-219.

Winkelman, L.A., Elsasser, T.H. \& Reynolds, C.K. 2008. Limit feeding a high-energy diet to meet energy requirements in the dry period alters plasma metabolite concentrations but does not affect intake or milk production in early lactation. Journal of Dairy Science 91: 1067-1079. https://doi.org/10.3168/jds.2007-0434 